\title{
PENGARUH PEMBERIAN GARAM BERIODIUM TERHADAP KADAR TIROKSIN PADA IBU USIA SUBUR DI DAERAH ENDEMIK DEFISIENSI IODIUM
}

\author{
Basuki Budiman'; Komari ${ }^{1}$ dan Saidin ${ }^{1}$ \\ ${ }^{1}$ Pusat Penelitian dan Pengembangan Gizi, Badan Litbang Kesehatan Dep Kes
}

\section{ABSTRACT
THE EFFECT OF IODIZED SALT INTERVENTION ON THYROXINE OF CHILDBEARING AGE MOTHERS IN ENDEMIC IODINE DEFICIENCY AREA

\begin{abstract}
The national evaluation on implementation of lodized salt indicate an excess dietary intakes of iodine. It is a consequence of the correction of iodine deficiency. However there is no confirmation of the adverse effect to the excess in Indonesia. Our aim is to elaborate whether the excess of iodine consumption affect serum thyroxine. We supplied 50-ppm iodized salt to 82 mothers at childbearing age's family every two weeks for three months. We suggest the mothers used the supplied iodized salt for family consumption only and not used the salt for any other purposes such as cattle feeding. Mother's blood drawn before and after intervention. Urine iodine exretion (UIE) were collected from school age children of participant family. The study revealed that three month-iodized salt intervention increased median UIE by $18.4 \%$ and serum thyroxine level by $36.5 \%$. The number of children being at risk for hyperthyroidism were constributed from normal and deficit range level at initial study by $62,5 \%$ and $41.7 \%$ respectively. The number of mothers being thyroxine excess were 22.2 and $22.7 \%$ respectively. We conclude that the level of iodine consentration in salt at $50 \mathrm{ppm}$ is high and suggest that consentration should be lowered.
\end{abstract}

Keywords: EIU, at risk for hyperthyroidism, thyroid hormone excess.mother at child bearing age.

\section{PENDAHULUAN}

efisiensi iodium merupakan salah satu masalah gizi dunia yang diderita lebih dari sepertiga jumlah penduduk di dunia terutama di negara-negara berkembang. antara 1-10 persen menderita kretin, 5-30 persen gangguan perkembangan mental dan neuromotorik lain (brain damage), dan lebih dari 30 persen kehilangan energi akibat kekurangan iodium dan atau menifestasi defisiensi iodium lainnya yang dikenal dengan gangguan akibat kekurangan iodium $\left(\right.$ GAKI) ${ }^{(1)}$

Garam beriodium untuk penanggulangan masalah defisiensi telah dicanangkan sejak tahun 1990 (World Summit for Children) dengan target tahun 2000 tidak terlahir kretin baru. Semua negara yang mempunyai masalah defisiensi iodium mengadop program garam beriodium untuk semua (universal salt iodization, USI) termasuk Indonesia. ${ }^{(2)}$. Program garam beriodium untuk penanggulangan masalah GAKI telah dilaksanakan di tujuh negara pada tahun 1991 dan telah dievaluasi pula pada tahun 1995. Hasilnya cukup mengesankan. Di Zimbabwe, peningkatan konsumsi garam berioidum pada tingkat rumahtangga diikuti kenaikan konsentarasi iodium dalam urin pada anak usia sekolah dan kelipatan kejadian hipertiroidi. ${ }^{(3,4)}$

Profilaksis iodium melalui fortifikasi garam beriodium di berbagai negara dinilai berhasil namun juga menghasilkan efek samping yaitu ekses konsumsi iodium. Badan konsultasi penanggulangan GAKY Internasional (ICCIDD)/WHO menganjurkan 
fortifikasi garam dengan iodium dengan kadar 20-40 ppm iodium atau 34-66 ppm $\mathrm{KIO} 3$ dan menetapkan batas median EIU pada anak usia sekolah (6-12 tahun) $300 \mathrm{Ig} /$ $\mathrm{L}$ merupakan risiko hipertiroidi dan konsumsi ekses $^{(5)}$. Pada tingkat seluler, ekses iodium ditandai dengan terdepresinya kadar hormon tirotropin (TSH) disertai kadar tiroksin bebas dalam serum naik atau tetap dalam batas normal ${ }^{(6)}$.

Di Zimbwabwe, ketika konsumsi iodium meningkat 100 persen, rumahtangga yang mengonsumsi garam beriodium meningkat dari 5 menjadi 50 persen, median ekskresi iodium dalam urin (EIU) meningkat dari 20 menjadi $430 \mathrm{gg} / \mathrm{L}$ dan kejadian kelebihan hormon tiroid meningkat tiga kali lipat dalam kurun waktu lima tahun, yaitu tahun 1991 sampai dengan 1995. Kejadian kelebihan hormon tiroid juga ditemukan di Congo ${ }^{(3,4)}$. Program garam beriodium dilaporkan sukses di Cote d'Ivoire. Universal garam beriodium secara cepat membuat EIU menjadi normal. Rata-rata konsentrasi hormon tirotropin pada anak usia sekolah turun dan proporsi yang naik berkurang dalam kurun waktu satu tahun. Namun demikian terdapat 2-3 persen di antaranya yang mengalami kenaikan ${ }^{(7)}$. Di China, 'goiter rate', yang diukur dengan ultrasonografi, di daerah endemis defisiensi iodium ringan (mild) turun dari 18 menjadi 59 persen setelah 18 tahun profilaksis ${ }^{(8)}$. Masih di Cina juga, di daerah bentukan endapan banjir sungai kuning, ekses konsumsi iodium yang berasal dari air minum dilaporkan menyebabkan goiter dan kenaikan EIU (9). Khan (10) melaporkan konsumsi iodium $50 \mathrm{mg} /$ hari selama 32 bulan menaikkan konsentrasi iodium dalam urin dan dapat menurunkan proporsi pembesaran kelenjar tiroid dari 44 menjadi 30 persen dalam kurun waktu 40 minggu. Masih dalam laporan yang sama, pada orang dewasa, ekses konsumsi iodium memperbesar kelenjar tiroid 37 persen dalam kurun waktu 3 bulan dan menjadi normal dalam waktu 3 bulan kemudian, setelah pemberian iodium mega doses dihentikan. Di Swiss, kenaikan konsentrasi iodium yang difortifikasi pada garam dari 15 menjadi 20 ppm berhasil menurunkan prevalensi defisit konsumsi iodium pada anak-anak dan ibu hamil trimester 2-3 sekitar 40 persen (11) Penambahan zat gizi lain juga meningkatkan efektifitas garam beriodium. (12-14). India memfortifikasi garam dengan konsentarasi iodium sebanyak 15 ppm atau lebih. Hasilnya menunjukkan kenaikan konumsi iodium selama tahun 1990-an, konsumsi garam beriodium 15 ppm atau lebih pada tingkat rumahtangga sebesar 49 persen. Sekitar 22 persen rumahtangga menggunakan garam beriodium kurang dari 15 ppm dan 28 persen menggunakan garam yang tidak beriodium sama sekali. ${ }^{(15)}$

Indonesia melaksanakan program iodisasi garam untuk penanggulangan GAKI sebagai program jangka panjang sudah sejak tahun $1978^{(16)}$, di samping program jangka pendek yaitu pemberian iodium mega dosis intramuskuler dan kemudian mulai tahun $1992^{(17)}$ digantikan dengan kapsul minyak beriodium per oral. Masalah GAKI, yang tercermin dari prevalensi pembesaran kelenjar tiroid pada anak usia sekolah (6-12 tahun) sebesar 27,8 persen tahun 1992 berhasil ditanggulangi menjadi 9,6 (tahun 1998, tanpa Timor Timur) $)^{(18)}$ dan kemudian menjadi 11,1 persen tahun $2003^{(19)}$. Pada survei evaluasi gaki tahun 2003, secara nasional, proporsi EIU di atas $300 \mathrm{gg} / \mathrm{L} 35$ persen dan proporsi berbagai propinsi berkisar antara15,2 (propinsi Bali) sampai dengan 54,7 persen (propinsi Bangka Belitung).

Kadar tiroksin dalam serum merupakan gambaran kasar fungsi tiroid dalam menggunakan iodium. Publikasi penelitian tentang pengaruh konsumsi garam beriodium terhadap kenaikan hormon tiroksin (T4) masih sedikit termasuk di Indonesia. Untuk mengetahui efek pemberian garam beriodium terhadap kadar tiroksin telah dilakukan penelitian ekperimen kuasi terhadap rumahtangga yang beranggotakan ibu usia subur dan anak usia sekolah.

\section{BAHAN DAN CARA}

Penelitian ini dilaksanakan di kota Batu, di daerah replete (mantan) endemik 
defisiensi iodium dengan intensitas berat tahun 1998. Partisipan penelitian adalah ibu rumahtangga usia 23-35 tahun yang mempunyai anak usia sekolah, tidak sedang haid saat pengambilan darah tidak sedang hamil, tidak sedang dalam masa menyusui atau pengobatan tiroid serta tidak menggunakan alat kontrasepsi hormonal. Sebanyak 82 partisipan dipilih dari hasil penapisan anak sekolah dasar di dua kecamatan. Wanita yang anaknya mengalami pembesaran kelenjar tiroid yang tampak waktu tengadah (IB) dan atau teraba (IA) terpilih sebagai partisipan. Pembesaran kelenjar dilakukan dengan perabaan (palpasi).

Partisipan yang terpilih, selama tiga bulan dipasok garam beriodium yang mengandung iodium 50 ppm. Agar terjamin kadar iodium yang terdapat dalam garam, iodisasi dibuat sendiri di Pusat Penelitian dan Pengembangan Gizi. Pemasokan garam sebanyak 800 gram dilakukan setiap dua minggu dan jumlah garam yang berkurang diasumsikan sebagai garam yang dikonsumsi keluarga. Sebelum pemberian garam beriodium diserahkan, dijelaskan larangan penggunaan garam lain dan partisipan hanya menggunakan garam beriodium yang dipasok oleh peneliti. Garam yang dipasok terbungkus plastik dalam wadah tertutup (toples plastik). Oleh karena alasan operasional, garam dibagikan melalui anak di sekolah.

Kadar serum hormon tiroksin partisipan diperiksa pada awal dan akhir penelitian (3 bulan kemudian). Pemeriksaan ekskresi iodium dalam urin pada anak sekolah yang menjadi partisipan juga diperiksa pada awal dan akhir penelitian. Pemeriksaan kadar tiroksin dan iodium diperiksa di laboratorium Pusat Penelitian dan Pengembangan Gizi, Badan Litbang Kesehatan di Bogor.

Oleh karena penelitian ini memberikan perlakuan, ethical clearence telah diperoleh dari Komisi Etik Badan Penelitian dan Pengembangan Kesehatan. Persetujuan setelah penjelasan penelitian (informed consent) juga diperoleh dari partisipan secara tertulis.

\section{HASIL}

Jumlah anak yang menyerahkan urin awal dan akhir (berpasangan) sebanyak 74 anak. Oleh karena terdapat jeda penapisan (skreening) dengan perlakuan yang melewati masa pergantian tahun ajaran, anak kelas enam sudah melanjutkan ke SMP sedangkan kesediaan partisipan telah tercatat sebelumnya sehingga beberapa anak tidak dapat dilacak keberadaannya. Median EIU anak usia sekolah yang menjadi sampel pada awal penelitian 207 dan naik menjadi $245 \mathrm{gg} / \mathrm{L}$ dengan proporsi EIU normal, defisit iodium, berisiko hipertiroidi (di atas $200 \mathrm{Ig} / \mathrm{L}$ ) masing-masing 32,4; 16,2 dan 51.4 persen.

Selama tiga bulan, median ekskresi iodium dalam urin pada anak sekolah (keluarga partisipan) mengalami kenaikan 18,4 persen dan proporsi anak yang defisit iodium berkurang sampai 97,8 persen; namun jumlah anak yang berisiko hipertiroidi (EIU>201) naik sebesar 8,1 persen. Menarik disimak bahwa lebih dari separuh anak-anak ini $(51.4 \%)$ pada awal penelitian telah berisiko hipertiroidi pada mereka sebagian besar mengalami pembesaran tiroid tingkat IB (posisi kepala tengadah, pembesaran kelenjar tiroid tampak). Jika diperiksa lebih teliti, proporsi anak yang berisiko hipertiroidi terjadi pada kondisi EIU awal normal dan defisit; eiu pada awal penelitian berisiko hipertiroidi justru menurun. Kondisi berisiko hipertiroidi setelah tiga bulan kemudian diperoleh dari median eiu pada awal penelitian normal dan defisit masing-masing sebesar 62,5 dan 41,7; sebaliknya yang pada awal penelitian memang berisiko hipertiroidi turun sebesar - 36,8 persen. (Tabel 1).

Perubahan yang terjadi pada EIU anak sekolah searah dengan perubahan tiroksin dalam serum darah ibu. Pada Tabel 2 disajikan perubahan hormon tiroksin ibu selama 3 bulan intervensi garam beriodium. Median tiroksin naik 36,5 persen dari 6,98 menjadi 9,30 ng/L dan proporsi ibu yang status tiroksinnya normal naik 25 persen. Kenaikan proporsi juga terjadi pada ibu yang pada ekses hingga lima kali lipat dan 
kenaikan ini disumbang dari status tiroksin yang normal $(22,2 \%)$ dan defisit $(22,7)$ pada awal penelitian.

\section{BAHASAN}

Penelitian ini adalah kuasi yang berbasis pada masyarakat dan disadari bahwa konsumsi garam oleh keluarga tidak dapat dikontrol secara penuh, walaupun peringatan tidak menggunakan garam lain telah diberikan pada awal penelitian dan terdapat pada wadah garam. Demikian pula kontrol terhadap konsumsi iodium dari sumber lain, misalnya mendapat makanan dari tetangga atau saudara selam tiga bulan perlakuan. Namun demikian, oleh karena konsumsi iodium sebagian besar konsumsi iodium dipastikan berasal dari garam beriodium yang dipasok kepada partisipan. Keterbatasan lain adalah data yang dikumpulkan juga meliputi perubahan konsentrasi iodium sampai rumahtangga. Penurunan konsentrasi garam dapat terjadi antara lain karena cara dan lama penyimpanan, kelembaban, pemasakan ${ }^{(20)}$. Pada penelitian ini tidak dikumpulkan data tersebut. Namun demikian, dilihat akibatnya, baik pada ibu dan anak, cukup besar. Konsumsi garam beriodium dengan konsentrasi 50 ppm di satu sisi dengan cepat telah menaikkan cadangan iodium dalam tubuh, namun di sisi lain mempunyai efek berlebihan (ekses). Penurunan konsentrasi iodium dalam garam karena penyimpanan mungkin tidak terjadi karena pasokan dilakukan tiap dua minggu, sehingga konsentrasi iodium dalam garam tetap terjaga. Penurunan kemungkinan terjadi pada waktu pemasakan, namun kehilangan iodium karena hal ini mungkin kecil sekali (< $10 \%$ ) sehingga pasokan pun tetap mencukupi.

Kadar tiroksin dalam serum dipengaruhi oleh penggunaan obat, perubahan hormonal karena kedaan biologis, misalnya sedang haid, hamil dan menggunakan alat kontrasepsi hormonal. Keadaan ini diantisipasi pada waktu penapisan. Inklusi partisipan telah menapis hal ini dan pengambilan darah tidak dilakukan pada ibu yang sedang sakit dan haid.

Penelitian terdahulu di banyak negara membuktikan bahwa konsentrasi iodium yang difortifikasikan pada garam dapat menormalkan kadar status iodium; di samping dapat menjadi ancaman terjadinya hipertiroidi. Di Zimbabwe, kejadian hipertiroidi terjadi sampai tiga kali. Ekses iodium terjadi pada awal ditemukan cara pengobatan defisiensi iodium, yang kemudian dikenal dengan efek 'JodeBasedow' (21).

Menurunnya risiko hipertiroidi karena iodium yang beredar dalam serum tinggi sehingga ekspresi sodium iodine sympoter (NIS), gen yang memediasi masuknya iodium ke dalam sel tiroid, menjadi tertekan. Akibatnya iodium terhambat masuk ke dalam sel tiroid. Pada gilirannya pembentukan hormon tiroid mengalami gangguan. (22-24). Kemungkinan ini terjadi karena pada awal penelitian konsumsi iodium memang sudah tinggi (median di atas 200) yang sudah mendekati taraf ekses. Hal ini tampak pada perubahan tiroksin ibu, yang pada awal penelitian ekses hanya tiga orang menjadi 15 orang pada akhir penelitian. Pada anak atau ibu yang pada awal penelitian iodium tubuhnya defisit iodium, kemungkinan akibat dari konsumsi iodium dengan konsentrasi tinggi dan berlangsung lama sebelum penelitian dilakukan. Kegagalan ekspresi NIS selanjutnya mengakibatkan rendahnya produksi hormon tiroid dan akhirnya hipotiroidi.

Pelajaran yang dari penelitian ini adalah pemberian konsentrasi idoium pada garam sebanyak 50 ppm tampaknya terlalu tinggi. Di India menggunakan 15 ppm. Pemerintah Swiss menaikkan konsentrasi 15 menjadi 20 ppm karena penggunaan garam meja oleh remaja dan ibu hamil semakin berkurang. WHO/UNICEF/ICCIDD menganjurkan batas 20 ppm iodium untuk daerah-daerah yang telah lama defisit iodium. Di Indonesia, pada waktu awal dipetakan daerah defisit iodium, diketahui daerah-daerah yang defisit adalah daerah defisit dengan intensitas berat. Pada dekade 90-an ketika garam iodium diperkenalkan disertai pemberian iodium 
secara masif per oral, jumlah daerah-daerah defisit iodium yang berat menurun dengan drastis. Daerah-daerah baru muncul mungkin bukan daerah defisit tetapi justru daerah yang ekses konsumsi iodium. Seperti diketahui pemeriksaan pembesaran tiroid menggunakan pemeriksaan palpasi dan hasilnya pada anak usia sekolah 6-12 tahun umumnya pembesaran kelenjar tiroid pada tingkat IA dan IB. Pada pembesaran tingkat ini, kesalahan diagnosis cukup besar. Tambahan pula, pembesaran kelenjar tiroid sering ditemukan pada penderita hipertiroidi. Klarifikasi tentang hal ini perlu dilakukan terutama bagi daerah-daerah yang telah lama mendapat intervensi iodium.

Asumsi konsumsi garam di Indonesia sekitar 10 gram mungkin betul, beberapa penelitian menyebutkan konsumsi garam per orang per hari antara 6-12 gram, tetapi untuk humiditas /kelembaban sangat bervariasi kehilangan di daerah dengan curah hujan tinggi dan rendah, daerah pegunungan dan pantai, lama pemakaian garam yang telah dibeli, kebiasaan penggunaan garam diberbagai kelompok masyarakat. Demikian pula perlu dipertimbangkan kebenaran asumsi bahwa setiap rumahtangga mengkonsumsi garam dalam jumlah yang sama. Fakta menunjukkan sekelompok remaja tidak menyukai masakan yang berkuah, padahal garam tampaknya paling banyak digunakan untuk masakan berkuah, sementara masyarakat Indonesia belum terbiasa menggunakan garam meja yang ditaburkan sebelum makan.

\section{KESIMPULAN}

Perubahan tiroxin agaknya cukup untuk mendasari penarikan kesimpulan bahwa fortifikasi garam dengan iodium pada konsentrasi 50 ppm dapat berakibat ekses iodium dalam waktu relatif singkat.

\section{SARAN}

Diturunkan konsentrasi iodium untuk garam fortifikasi menjadi $15-20$ ppm pada tingkat konsumen

\section{RUJUKAN}

1. Stanbury, JB. (Editor). The Damaged Brain of lodine Deficiency. CognitiveBehavioral-Neuromotor-Educative

Aspects. Cognizant Communication Corporation. New York-Sidney-Tokyo. 1995.

2. ICCIDD. World summit for children pledges elimination of iodine deficiency by the year 2000. IDD Newsletter. 1990;6(4):1-8

3. Joint WHO/UNICEF/ICCIDD Consultation. Review on finding from 7country study in Africa on Levels of salt iodization in relation to iodine deficiency disorders, including iodine induce hyperthyroidism. Food and Nutrition Library (FNL) 2001.[CD-ROM Version 3.0]

4. Stanbury, JB., dkk.. lodine Induced Hyperthyroidism: Occurance and Epidemiology in Report of workshop on lodine Induced Hyperthyroidism, organized by ICCIDD march 1996. Thyroid 1998;8(1): 83-100

5. ICCICC/UNICEF/WHO. Assessment of iodine deficiency disorders and monitoring their elimination- a guide for programme managers. 2 edn. WHO/NHD/01.1. 2001

6. Fatourechi V. Adverse effects of subclinical hyperthyroidism. The Lancet $2001 ; 358: 856-7$

7. Zimmermann MB, Hess SY, Adou P, Toresanni T, Wegmuler R, Hurrel RF. Thyroid size and goiter prevalence after introduction of iodized salt: a 5-y prospective study in schoolchildren in Cote d'Ivoire. AJCN 2003;77:663-7

8. Zimmermann, MB, Adou P, Torresani T, Zeder C, Hurrel RF. Persistence of goiter despite oral iodine supplementation in goitrous children with iron deficiency anemia in Cote d'Iviore. AJCN 2000;71: 88-93 
9. Zhao, Jinkou, Wang $P$, Sullivan $K M$, vd Haar F, Maberly G. Endemic Goiter Associated with high lodine intake. AJPH. 2000;90:1633-1635

10. Khan LK, Li R, Gootnik D. Thyroid abnormalities related to iodine excess from water purification units. Peace Corps Thyroid Investigation Group. Lancet, 1998;352:1519

11. Zimmermann MB, Aeberli I, Torresani T, Burgi $H$. Increasing the iodine concentration in Swiss iodized salt program markedly improved iodine status in pregnant women and children: a 5 -y prospective national study. Am J Clin Nutr 2005;82:388-92.

12. Zimmermann, MB, Wegmuller R, Zeder $C$, Chaouki N, Torresani T. The effect of vitamin A Deficiency and vitamin A supplementation on Thyroid Function in Goitrous Children. JCEM 2004;89: 5441-7

13. Hess, Sonja Y, Zimmermann MB, Adou P, Torresani T, Hurrel RF. Treatment of iron deficiency in goitrous children improves the efficacy of iodized salt in Cote d'Iviore. AJCN 2002;75:743-8

14. Zimmermann, MB, Wegmuller $R$, Zeder C, Chaouki N, Beibinger R, Hurrel RF, Windhab E. Triple fortification of salt with microcapsules of iodine, iron and vitamin A. AJCN. 2004. 80:1283-90

15. Ramachandran $P$. Lesson learnt from the national programme for food and micronutrients supplementation in India. SCN 2003;26:18-20. tersedia pada URL http://www.unsystem.org/scn/

16. Djokomoeljanto, Satoto dan Untoro R. IDD Control in Indonesia. In Hetzel B (senior Ed), Delange F, Dunn J, Ling J, Mannar V, Pandav C (Eds). Towards The Global elimination of brain damage due to iodine deficiency. First Prt. Oxford. India. 2004:422-436
17. Departemen Kesehatan. Distribusi kapsul minyak beriodium. 2000

18. Departemen Kesehatan. Survai Nasional Pemetaan Gangguan Akibat Kekurangan Yodium (GAKY). Proyek Intensifikasi Penanggulangan GAKY IBRD-Loan 4125-IND Kerjasama Pusat Pnelitian dan Pengembangan Gizi dan Direktorat Bina Gizi Masyarakat DepKes Republik Indonesia. 1998.

19. Departemen Kesehatan. Survai Nasional Pemetaan Gangguan Akibat Kekurangan Yodium (GAKY). Proyek Intensifikasi Penanggulangan GAKY. Evaluasi program GAKI. 2003

20. ICCIDD/UNICEF/WHO. Recommended lodine Level in Salt and Guidelines for monitoring their adequacy and effectiveness. 1996. FNL version 3.0 [CD-ROM].

21. Stanburry JB, Ermans $A E$, Bourdoux $P$, Todd C, Oken E, Tonglet R, Vidor G, Braverman LE, Medeiros-Neto $G$. lodine-Induced Hyperthyrodism: Occurrence and epidemiology. Thyroid 1998;8(1):83-100

22. Carrasco N. Thyroid hormone synthesis-thyroid iodine transport in Braverman LE and Utiger RD (Eds) The Thyroid-A Fundamental and Clinical Text. 9th ed. Lippincott Williams \& Walkins. Philadelphia. 2005: 37-52

23. Dohan O, DeLa Vieja A, Paroder V, Riedel C, Artani M, Reed M, Ginter CS, Carrasco N. The Sodium/lodide Symporter (NIS): Characterization, Regulation, and Medical Significance. Endocrine Reviews 2003:24:48-77. download from http://www.edrv.endojournals.org on june 12, 2006.

24. Shen DHY, Kloos RT, Mazzferri EL, Jhiang SM. Sodium lodide Symporter in Health and Disease. Thyroid 2001;11(5):415-425 
Tabel 1

Status ekskresi lodium dalam urin (EIU) anak usia sekolah pada alwal dan akhir penelitian

\begin{tabular}{|c|c|c|c|c|c|c|}
\hline & & & \multicolumn{3}{|c|}{ Status EIU pada akhir penelitian } & \multirow{2}{*}{$\begin{array}{c}\text { Total } \\
\text { ElUawal }\end{array}$} \\
\hline & & & $\begin{array}{l}\text { normal, } \\
100-200\end{array}$ & $\begin{array}{l}\text { defisit, } \\
<100\end{array}$ & $\begin{array}{c}\text { berisiko } \\
\text { hiper, } 201+\end{array}$ & \\
\hline \multirow[t]{9}{*}{$\begin{array}{l}\text { Status EIU } \\
\text { AS awal }\end{array}$} & normal, $100-200$ & $\mathrm{~N}$ (anak) & 8 & 1 & 15 & 24 \\
\hline & & $\%$ terhadap total awal & $33.3 \%$ & $4.2 \%$ & $62.5 \%$ & $100.0 \%$ \\
\hline & & $\%$ terhadap total akhir & $28.6 \%$ & $50.0 \%$ & $34.1 \%$ & $32.4 \%$ \\
\hline & defisit, $<100$ & $\mathrm{~N}$ (anak) & 6 & 1 & 5 & 12 \\
\hline & & $\%$ terhadap total awal & $50.0 \%$ & $8.3 \%$ & $41.7 \%$ & $100.0 \%$ \\
\hline & & $\%$ terhadap total akhir & $21.4 \%$ & $50.0 \%$ & $11.4 \%$ & $16.2 \%$ \\
\hline & $\begin{array}{l}\text { berisiko hiper, } \\
201+\end{array}$ & $\mathrm{N}$ (anak)Count & 14 & 0 & 24 & 38 \\
\hline & & $\%$ terhadap total awal & $36.8 \%$ & $.0 \%$ & $63.2 \%$ & $100.0 \%$ \\
\hline & & $\%$ terhadap total akhir & $50.0 \%$ & $.0 \%$ & $54.5 \%$ & $51.4 \%$ \\
\hline \multirow[t]{3}{*}{ Total } & & $\mathrm{N}$ (anak) & 28 & 2 & 44 & 74 \\
\hline & & $\%$ terhadap total awal & $37.8 \%$ & $2.7 \%$ & $59.5 \%$ & $100.0 \%$ \\
\hline & & $\%$ terhadap total akhir & $100.0 \%$ & $100.0 \%$ & $100.0 \%$ & $100.0 \%$ \\
\hline
\end{tabular}

Keterangan : Median EIU (min-max) $\rightarrow$ awal : 207(40-480), akhir: 245(79-812) 
Tabel 2

Perubahan status tiroxin dalam serum ibu usia subur 23-35 tahun selama tiga bulan intervensi garam beriodium

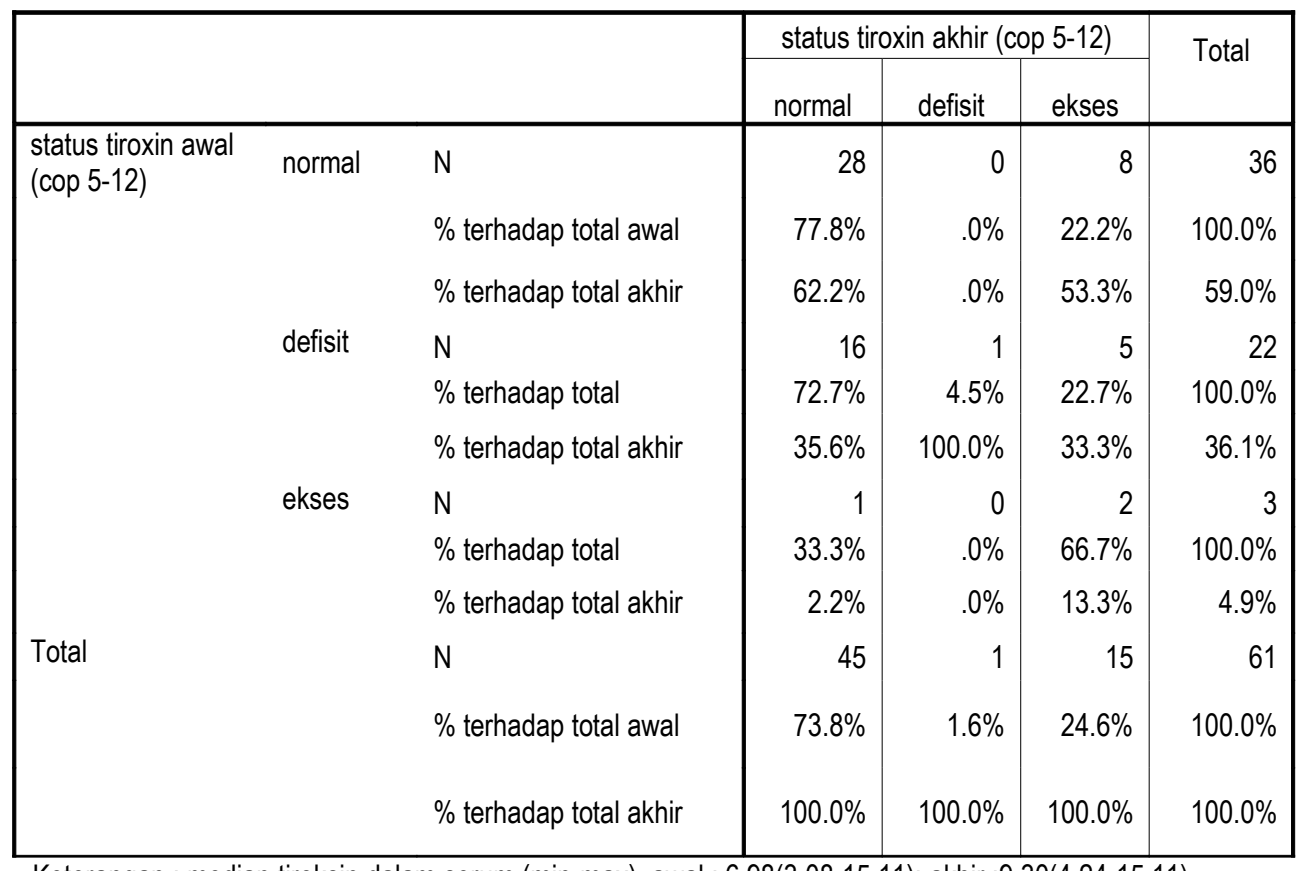

Keterangan : median tiroksin dalam serum (min-max), awal : 6,98(3,08-15,11); akhir :9,30(4,24-15,11) 